\title{
Health Academy Program and physical activity levels in Brazilian state capitals
}

\section{Programa Academia da Saúde e níveis de atividade física nas capitais brasileiras}

\section{AUTHOR'S \\ Thania Mara Teixeira Rezende Faria ${ }^{1}$ (D) \\ Stephan Brenner ${ }^{2}$ iD \\ Andreas Deckert ${ }^{2}$ (D) \\ Alex Antonio Florindo ${ }^{3}$ (D) \\ Gregore Iven Mielke ${ }^{4}$ (D) \\ 1 Secretaria Municipal de Saúde, Belo Horizonte, Minas Gerais, Brasil. \\ 2 Universidade de Heidelberg, Institute of Global \\ Health, Heidelberg, Alemanha. \\ 3 Universidade de São Paulo, Escola de Artes, \\ Ciências e Humanidades, São Paulo, São Paulo, \\ Brasil. \\ 4 The University of Queensland, School of Human \\ Movement and Nutrition Sciences, Brisbane, \\ Queensland, Australia.}

\section{CORRESPONDING}

Thania Mara Teixeira Rezende Faria

thania_faria@hotmail.com

Avenida Novara 80, apt. 201 bloco 09,

Bandeirantes. Belo Horizonte, Minas Gerais,

Brasil.

CEP: $31340-640$.

DOI

10.12820/rbafs. $25 \mathrm{e} 0133$

\section{(cc) BY}

This work is licensed under a Creative Commons Attribution 4.0 International License.

\begin{abstract}
The objective of this study was to analyze the impact of a community-based physical activity program, the Health Academy Program (Academia da Saúde or PAS), on leisure-time physical activity (LTPA) among the population living at the Brazilian state capitals. We pooled individual data from the National Surveillance for Protective and Risk Factors for Chronic Diseases (VIGITEL) between 2006 and 2016 and estimated odds ratios according to levels of exposure by using a multilevel logistic regression. Total sample was composed of 572,437 individuals. In the initial model, chances of reaching sufficient LTPA was 1.20 (95\%CI: 1.16-1.25) times higher among individuals exposed since 2011. In the analyses adjusted for year, sex, age and education, this probability was only 1.04 (95\% CI: 1.00-1.08) times higher among exposed individuals. Odds of reaching recommended LTPA was 1.09 (95\%CI: 1.04-1.15) times higher among women exposed since 2011 as compared to women in the control group with no exposure. No other statistically significant results were found. We conclude that the PAS cannot substantially affect whole populations. Yet it is possible to visualize a positive influence of the program on specific subgroups, pointing to its potential to reduce gender inequity in LTPA practice. We recommend more tailored interventions before indistinctively scaling up the program, as well as we suggest better monitoring for large scale evaluations.
\end{abstract}

Keywords: Public health practice; Physical activity; Health promotion, Primary health care, Evaluation.

\section{RESUMO}

O objetivo deste estudo foi analisar o efeito de um programa de atividade física de base comunitária, o Programa Academia da Saúde (PAS), no nivel de atividade física durante o lazer (AFDL) da população residente nas capitais brasileiras. Reunimos dados individuais do sistema de Vigilância de Fatores de Risco e Proteção para Doenças Crônicas por Inquérito Telefônico (VIGITEL) entre 2006 e 2016 e estimamos os odds ratios de acordo com níveis de exposição ao programa usando uma regressão logistica multinivel. A amostra total foi composta por 572.437 indivíduos. No modelo inicial, as chances de se atingir niveis suficientes de AFDL foram 1,20 (95\%IC: 1,16-1,25) vezes maior entre os indivíduos expostos desde 2011. Nas análises ajustadas por ano, sexo, idade e escolaridade, essa probabilidade foi apenas 1,04 (95\%IC: 1,001,08) vezes maior entre individuos expostos. As chances de se atingir niveis de AFDL suficiente foram 1,09 (95\%IC: 1,04-1,15) vezes maior entre as mulheres expostas desde 2011 em comparação ao grupo controle de mulheres não expostas. Nenhum outro resultado estatisticamente significativo foi encontrado. Concluimos que o PAS não pode afetar substancialmente populaçôes inteiras. No entanto, é possivel visualizar influência positiva em subgrupos específicos, apontando para o seu potencial em reduzir a desigualdade de gênero em relação a prática de AFDL. Recomendamos intervençôes mais personalizadas antes de escalonar indistintamente o programa, bem como sugerimos um melhor monitoramento para avaliaçôes em larga escala.

Palavras-chave: Prática de saúde pública; Atividade física; Promoção da saúde, Atenção primária, Avaliação.

\section{Introduction}

Physical inactivity is the fourth leading factor for global mortality and one among the main risk factors for non-communicable diseases (NCDs) ${ }^{1}$. Globally, diabetes, cancers, cardiovascular diseases and chronic respiratory diseases, account for $70 \%$ of the total number of deaths ${ }^{2}$. In Brazil, NCDs were responsible for $75.8 \%$ of deaths in 2015 , with physical inactivity heavily contributing to increased disability-adjusted life years in the country ${ }^{2}$.
While physical inactivity was regarded as a global pandemic, countries worldwide were called to invest in population level policy and action plans to address the situation ${ }^{3}$. In this sense, as a follow-up of strategies, the Brazilian Ministry of Health launched in 2011 a community-based physical activity (PA) program called Programa Academia da Saúde (PAS or, in English, Health Academy Program) in alignment with the national and global agendas for the prevention and control of NCDs. 
The Academia da Saúde program, or PAS, was conceptualized in earlier years by cities that developed similar initiatives in different regions of Brazil and were later granted similarity to the national program. Official similarity can be claimed if the respective PA project complies with the prerequisites of having a built area exclusively for the program, a minimum of one health professional working for 40 hours per week, activities in at least two daily shifts, commitment to the program's objectives, financial responsibility and management under supervision of the Municipal Secretary of Health ${ }^{4}$.

Academia da Saúde is characterized by free supervised classes to the population. The sessions are guided by physical education professionals who also develop educational activities and health promotion interventions in cooperation with the health facilities ${ }^{5}$. Classes include guided walks, aerobic activities and resistance training exercises (i.e. strength or weight training) in the format of a 50-minute session, three times a week for each individual ${ }^{6,7}$. Ordinance $n^{\circ} 719 / 2011$ from the Ministry of Health (later revoked and replaced by Ordinance $n^{\circ}$ 2681/2013), which created the PAS, defined that the objectives of the program are not only to promote PA and exercise practice, but also to stimulate better diet, promote community mobilization and cultural manifestation, strengthen intersectoral actions and stimulate the individuals to take healthier choices ${ }^{8}$.

While designed for people of all ages, Academia da Saúde predominantly serves the adult population in most vulnerable areas of the city ${ }^{9}$, capturing within its activities mainly elderly individuals, women and others with an average age of 48 years and elevated metabolic risk, including overweight and hypertension ${ }^{10}$. Currently, the program is present in approximately 2,849 Brazilian cities ${ }^{11}$, which accounts for more than half of the total number of cities in the country. The program may reach over 1 million people in $25 \%$ of those cities ${ }^{12}$ and its effects are extended directly and indirectly to many others through health promotion actions and communication $^{13}$.

Overall, community-based interventions have been found to be effective strategies for reducing physical inactivity in Latin America ${ }^{14}$. The effect of Academia da Saúde in Brazil has been demonstrated both as regards the increase of leisure-time physical activity (LTPA) among participants ${ }^{15}$ and non-participants of the program who have heard or seen the activities ${ }^{16,17}$. In this regard, residing geographically close to the program has also promoted higher utilization of public spaces for the practice of PA among non-participants ${ }^{18,19}$.

At city-level, Simões et al. ${ }^{13}$ estimated the effect of different degrees of exposure on the achievement of sufficient LTPA among residents of various municipalities in the state of Pernambuco. The study investigated the odds of being active during leisure through a wedge-design that evaluates effectiveness at community level when an intervention had already shown to be effective at individual level. Odds of reaching sufficient LTPA in the population increased among women living at cities where the program was implemented for less than three years and even more at statistically significant levels among those women living at cities where Academia da Saúde was implemented for more than three years ${ }^{13}$.

Therefore, in order to provide more comprehensive information at national level, the aim of this study was to analyze the effect of the Academia da Saúde program implementation on LTPA in the Brazilian population of state capitals where the program was implemented. Our study assumes Academia da Saúde to affect citizens' behavior regarding LTPA through a combination of educational and participatory interventions. We based our hypothesis on an ecological model that assumes that both direct and indirect reach can contribute to scale up LTPA at population level.

\section{Methods}

This study used secondary data from different sources. Firstly, data on the implementation of Academia da Saúde in each city were obtained from published articles, reports of the program, official websites and information provided by Municipal and State Secretaries of Health made available to the general public. Secondly, the prevalence of PA at individual level was extracted from the National Surveillance for Protective and Risk Factors for Chronic Diseases (VIGITEL). This is a surveillance system that uses telephone-based methods to interview adults living in the 27 Brazilian capitals, being representative of the entire respective population. Details about the methods have been $\mathrm{pu}^{-}$ blished elsewhere ${ }^{20,21}$.

In summary, respondents were identified by a multi-stage probabilistic sampling approach and drawn from records of registered landline telephones. In a first stage, 5,000 telephone lines were randomly selected from phone company registers in each city ${ }^{21}$. Phone lines pertaining businesses or companies, phonelines that were no longer in service and those not responding 
to a contact call after six attempts at different days and times, including weekends and nights, were excluded ${ }^{21}$. In a second stage, from all eligible lines, an average of 2,000 individuals were selected to be interviewed for the survey. For each selected household, one adult (18+ years) was randomly selected to be interviewed ${ }^{22}$. To minimize selection bias, VIGITEL included post-stratification weights for each respondent accounting for differences in the number of telephone lines in households, the number of adults in a household, and the non-sampling of non-landline households based on projections of the 2010 National Census.

The main outcome variable, namely "sufficient LTPA", was selected to measure the effect of exposure. LTPA is an indicator composed by the multiplication of the answer categories related to the survey questions assessing "type of activity" (moderate versus vigorous), "duration of activity" (minutes of uninterrupted exercise per PA session) and "frequency of activity" (number of days per week). The questions used to construct this indicator were "In the last three months, did you practice some form of physical exercise or sport?"; "What is the main type of physical exercise or sport that you practiced?"; "In how many days per week do you usually practice a physical exercise or sport?"; "On the day that you practice an exercise or sport, for how long does this activity last?".

Time practicing vigorous PA weights two times that of moderate PA due to the higher intensity and energy expended during exercise. Moderate types of PA include walking, swimming, and dancing; and vigorous $\mathrm{PA}$ include running, aerobic gymnastics and most of the team sports. Physically active individuals are those who accumulate 150 minutes of moderate PA per week or 75 minutes of vigorous PA per week; i.e. sufficient LTPA consists of exercising for an average of 30 minutes in at least 5 days/week or 25 minutes in at least 3 days/week.

Finally, for each survey year and city, exposure to the program was classified in three levels considering its national definition in 2011: a) control or "no PAS"; b) "short exposure"; i.e. exposure for less than 5 years by 2016 and; c) "long exposure"; i.e. exposure for more than 5 years by 2016. Residents of state capitals that hosted projects which were granted official similarity were considered as "long exposure". Potential confounding variables of the effect of Academia da Saúde on LTPA were sex (male or female), age in years, education in years $(0-8,9-11$ and $12+)$ and the variable year, rep- resenting the time when each survey was performed.

Individual and city-level data were pooled into a single dataset. Each individual information was matched to the city-level exposure at certain years. For example, a participant living in Rio de Janeiro in 2010 would be classified as either control, long-term or short-term exposure depending on the year when PAS was implemented. We used this approach to compare city populations exposed to the PAS with city populations not exposed to the program at a given time. We conducted both descriptive and inductive analyses. Frequencies were used to illustrate the distribution of outcome and confounding variables for each exposure group.

We used multilevel logistic regression analysis to estimate the odds ratios for the relationship between exposure and outcome variables. For the multilevel analysis, we defined individual participants as level 1 and Brazilian state capitals as level 2 because respondents are selected according to city clusters. An initial regression model included only the respective exposure and outcome variables. In the adjusted model, we controlled for year of survey, sex, age and education. We further performed stratified analyses by sex (male and female) and age ( $\geq 45$ years and $<45$ years). The significance level adopted was $\mathrm{p}<0.05$. All analyses were conducted in Stata/IC 15.1.

Our study relied solely on secondary data. The ethics committee of the University of Heidelberg, therefore, formally exempted this study from ethical review. The original VIGITEL survey was approved by the National Research Ethics Commission (CONEP) of the Brazilian Ministry of Health under protocol $n^{\circ} 749 / 2006$ and informed consent was obtained from all individual participants included in the survey.

\section{Results}

The original pooled sample included 572,437 individuals. The status of PAS implementation and the percentage of elderly population in each capital is presented in Table 1. By 2016, Academia da Saúde was implemented in 11 out of the 27 Brazilian capitals. Seven Brazilian capitals had started programs officially similar to PAS before 2011: Belo Horizonte (2006), Recife (2002), Aracaju (2004), Vitória (1990), Curitiba (1998), São Paulo (1996) and Rio de Janeiro (2009). Four capitals initiated the PAS in or after 2011: Rio Branco (2011), Boa Vista (2011), Salvador (2011) and João Pessoa (2015). Sixteen capitals either implemented the PAS after 2016 or not at all. 
The distribution of outcomes and confounding variables between groups is shown in Table 2. The prevalence of LTPA was $18.6 \%$ among participants living

Table 1 - Year of exposure to Academia da Saúde according to selected criteria and first similar physical activity initiative in each Brazilian capital.

\begin{tabular}{|c|c|c|c|c|c|}
\hline $\begin{array}{l}\text { Regions and } \\
\text { states }\end{array}$ & Capital & $\begin{array}{l}1^{\text {st }} \mathrm{PA} \\
\text { action }\end{array}$ & $\mathrm{PAS}^{\mathrm{c}}$ & $\begin{array}{c}\text { Source of } \\
\text { information }^{\mathrm{d}}\end{array}$ & $\begin{array}{l}\% \text { of } \\
\text { elderly } \\
\text { pop. }\end{array}$ \\
\hline \multicolumn{6}{|l|}{ North } \\
\hline Acre & Rio Branco & 2011 & 2011 & E-mail & $6.2 \%$ \\
\hline Amapá & Macapá & - & - & $\begin{array}{l}\text { Published } \\
\text { article }^{15}\end{array}$ & $5.1 \%$ \\
\hline Amazonas & Manaus & - & - & E-mail & $6.0 \%$ \\
\hline Pará & Belém & - & - & E-mail & $9.1 \%$ \\
\hline Rondônia & Porto Velho & - & - & E-mail & $5.6 \%$ \\
\hline Roraima & Boa Vista & 2011 & 2011 & E-mail & $5.1 \%$ \\
\hline Tocantins & Palmas & - & - & E-mail & $4.4 \%$ \\
\hline \multicolumn{6}{|l|}{ Northeast } \\
\hline Alagoas & Maceió & - & - & E-mail & $8.3 \%$ \\
\hline Bahia & Salvador & 2011 & 2011 & E-mail & $9.2 \%$ \\
\hline Ceará & Fortaleza & - & - & E-mail & $9.6 \%$ \\
\hline Maranhão & São Luís & - & - & E-mail & $7.6 \%$ \\
\hline Paraíba & João Pessoa & 2015 & 2015 & Website & $10.3 \%$ \\
\hline Pernambuco & Recife & $2002^{a}$ & 2006 & Website & $11.9 \%$ \\
\hline Piauí & Teresina & - & - & Website & $8.3 \%$ \\
\hline $\begin{array}{l}\text { Rio Grande } \\
\text { do Norte }\end{array}$ & Natal & - & - & E-mail & $10.4 \%$ \\
\hline Sergipe & Aracaju & $2004^{a}$ & 2006 & E-mail & $9.0 \%$ \\
\hline \multicolumn{6}{|l|}{ Central-west } \\
\hline Goiás & Goiânia & - & - & E-mail & $13.7 \%$ \\
\hline Mato Grosso & Cuiabá & - & - & E-mail & $8.2 \%$ \\
\hline
\end{tabular}

in cities without PAS. LTPA prevalence was 19.4\% among individuals with short exposure and 15.7\% among those with long exposure to the program.

\begin{tabular}{|c|c|c|c|c|c|}
\hline $\begin{array}{l}\text { Regions and } \\
\text { states }\end{array}$ & Capital & $\begin{array}{l}1^{\text {st }} \mathrm{PA} \\
\text { action }\end{array}$ & $\mathrm{PAS}^{\mathrm{c}}$ & $\begin{array}{l}\text { Source of } \\
\text { information }\end{array}$ & $\begin{array}{l}\% \text { of } \\
\text { elderly } \\
\text { pop. }\end{array}$ \\
\hline $\begin{array}{l}\text { Mato Grosso } \\
\text { do Sul }\end{array}$ & $\begin{array}{l}\text { Campo } \\
\text { Grande }\end{array}$ & - & - & E-mail & $9.9 \%$ \\
\hline Distrito Federal & Brasília & - & - & E-mail & $7.6 \%$ \\
\hline \multicolumn{6}{|l|}{ Southeast } \\
\hline Espírito Santo & Vitória & $1990^{\mathrm{a}}$ & 2006 & E-mail & $12.0 \%$ \\
\hline Minas Gerais & $\begin{array}{c}\text { Belo } \\
\text { Horizonte }\end{array}$ & $2006^{a}$ & 2006 & $\begin{array}{l}\text { Website/ } \\
\text { reports }\end{array}$ & $12.7 \%$ \\
\hline São Paulo & São Paulo & $1996^{\mathrm{b}}$ & 2006 & E-mail & $11.9 \%$ \\
\hline Rio de Janeiro & Rio de Janeiro & $2009^{b}$ & 2009 & E-mail & $14.9 \%$ \\
\hline \multicolumn{6}{|l|}{ South } \\
\hline Paraná & Curitiba & $1998^{\mathrm{b}}$ & 2006 & E-mail & $11.2 \%$ \\
\hline $\begin{array}{l}\text { Rio Grande } \\
\text { do Sul }\end{array}$ & Porto Alegre & - & - & E-mail & $15.1 \%$ \\
\hline $\begin{array}{l}\text { Santa } \\
\text { Catarina }\end{array}$ & Florianópolis & - & - & E-mail & $11.2 \%$ \\
\hline
\end{tabular}

a = official similarity to Academia da Saúde or Health Academy

Program granted in 2011; b = official similarity to Academia da Saúde or Health Academy Program granted in 2014; c = Academia da Saúde or Health Academy Program: cities with early physical activity initiatives (before Ordinance no719/2011) which were later granted PAS official similarity are considered exposed as early as the first year within VIGITEL, 2006-2016; d = e-mails obtained through the official website of the Ministry of Health and remaining sources obtained through an online search with the indexed words Academia da Saúde and the respective name of the capital. Reports of the program made available to the general public and published manuscripts confirmed the information provided by Municipal and State Secretaries of Health; e = data from 2010 according to the Brazilian Institute of Geography and Statistics (IBGE).

Table 2 - Sample characteristics according to exposure to Academia da Saúde in the Brazilian Capitals and Federal District, VIGITEL 20062016.

\begin{tabular}{|c|c|c|c|c|c|c|c|c|}
\hline \multirow{2}{*}{ Variables } & \multicolumn{2}{|c|}{$\begin{array}{c}\text { Total population } \\
2006-2016\end{array}$} & \multirow{2}{*}{\multicolumn{2}{|c|}{$\begin{array}{c}\begin{array}{c}\text { Control } \\
\text { (no PAS) }\end{array} \\
\%(95 \% \mathrm{CI})\end{array}$}} & \multirow{2}{*}{\multicolumn{2}{|c|}{$\begin{array}{c}\begin{array}{c}\text { Short PAS } \\
\text { (after 2011) }\end{array} \\
\%(95 \% \mathrm{CI})\end{array}$}} & \multirow{2}{*}{\multicolumn{2}{|c|}{$\begin{array}{c}\begin{array}{c}\text { Long PAS } \\
\text { (before } 2011)\end{array} \\
\%(95 \% \mathrm{CI})\end{array}$}} \\
\hline & $\mathrm{N}$ & $\%^{a}$ & & & & & & \\
\hline & & & & & & \multicolumn{3}{|c|}{ Sex } \\
\hline Women & 350,812 & 53.7 & 53.7 & $(53.4-54.0)$ & 54.2 & $(53.3-55.2)$ & 54.1 & $(53.6-54.6)$ \\
\hline Men & 221,625 & 46.3 & 46.3 & $(46.0-46.6)$ & 45.8 & $(44.9-46.7)$ & 45.9 & $(45.5-46.4)$ \\
\hline \multicolumn{9}{|l|}{ Age group } \\
\hline$<45$ years & 284,517 & 62.0 & 65.1 & $(64.9-65.4)$ & 64.2 & $(63.3-65.0)$ & 58.9 & $(58.5-59.4)$ \\
\hline$\geq 45$ years & 287,920 & 38.1 & 34.9 & $(34.7-35.1)$ & 35.9 & $(35.0-36.7)$ & 41.1 & $(40.6-41.5)$ \\
\hline \multicolumn{9}{|l|}{ Education (years) } \\
\hline 0 to 8 & 163,761 & 39.1 & 39.1 & $(38.8-39.4)$ & 33.8 & $(32.9-34.7)$ & 39.5 & $(39.1-40.0)$ \\
\hline 9 to 12 & 216,752 & 36.4 & 37.8 & $(37.6-38.1)$ & 44.1 & $(43.2-45.1)$ & 34.5 & $(34.0-34.9)$ \\
\hline$\geq 12$ & 191,924 & 24.5 & 23.1 & $(22.9-23.3)$ & 22.1 & $(21.4-22.8)$ & 26.0 & $(25.6-26.4)$ \\
\hline \multicolumn{9}{|l|}{ Sufficient LTPA ${ }^{\mathrm{b}}$} \\
\hline No & 466,456 & 82.8 & 81.4 & $(81.2-81.7)$ & 80.6 & $(79.9-81.4)$ & 84.3 & $(83.9-84.6)$ \\
\hline Yes & 105,981 & 17.2 & 18.6 & (18.4-18.8) & 19.4 & $(18.7-20.1)$ & 15.7 & $(15.4-16.1)$ \\
\hline Total $\mathrm{N}=$ & 572,437 & & & & & & & \\
\hline
\end{tabular}

$\mathrm{a}=$ column weighted percentages (\% using post stratification weights $)=\mathrm{n} /$ total exposed and unexposed groups; $\mathrm{b}=$ Leisure-time physical activity. 
The crude and adjusted odds ratios between exposure to the PAS and LTPA is presented in Table 3. The effect of the program on sufficient LTPA was positive and statistically significant among the population exposed for a shorter period of time both in the crude $(\mathrm{OR}=1.20 ; 95 \% \mathrm{CI}: 1.16-1.25)$ and adjusted analyses $(\mathrm{OR}=1.04 ; 95 \% \mathrm{CI}: 1.00-1.08)$.

Table 3 - Multilevel model for the effect of Academia da Saúde on sufficient LTPA.

\begin{tabular}{lcccc}
\hline & \multicolumn{4}{c}{ Sufficient LTPA } \\
\cline { 2 - 5 } & \multicolumn{2}{c}{ Initial model } & \multicolumn{2}{c}{ Adjusted model ${ }^{\mathrm{a}}$} \\
\cline { 2 - 5 } & OR & $\mathrm{P}$ & OR & $\mathrm{P}$ \\
& $(95 \% \mathrm{CI})$ & $\mathrm{p}$ CI $)$ & $\mathrm{p}$ \\
\hline No $^{\mathrm{b}}$ & 1.00 & & 1.00 & \\
Short $^{\mathrm{c}}$ & 1.20 & & 1.04 & 0.039 \\
& $(1.16-1.25)$ & $<0.001$ & $(1.00-1.08)$ & \\
Long $^{\mathrm{d}}$ & 1.04 & & 0.98 & 0.488 \\
\hline
\end{tabular}

$\mathrm{a}=$ model adjusted for year of survey, sex, age and education; $\mathrm{b}=$ control means that no Academia da Saúde is implemented; c = Academia da Saúde existing since 2011; d = Academia da Saúde existing since 2006.

Table 4 shows the results of the age-stratified and sex-stratified analyses for sufficient LTPA based on the adjusted model. Regarding PA levels, in the sex-stratified analysis, the likelihood of sufficient LTPA was 1.09 times higher (95\% CI: 1.04-1.15) and statistically significant among women exposed to the PAS shortly after 2011 as compared to unexposed women in the control group. This likelihood was not significant in any other stratified analyses.

\section{Discussion}

This study evaluated the influence of the Academia da Saúde program on a physical activity indicator, namely sufficient LTPA among residents of the Brazilian state capitals hosting the program. We observed a statisti- cally significant influence of PAS on sufficient LTPA among women residing at cities exposed to the program shortly after 2011.

Differently than demonstrated in previous studies ${ }^{13}$, we found that long term exposure seems not to be related to higher levels of LTPA, which may be associated to compliance with the objectives of Academia da Saúde according to national regulations and the confusion posed by official similarity granted to previously existing PA programs. The nationwide definition of the PAS in $2011^{23}$ helps explain the greater effect among "short exposure" residents, which may be a result of better alignment after its official regulation.

In accordance with the literature, we confirmed the relative indirect reach of the program ${ }^{13,16-19}$. There was a small visible effect in the total population after adjustment, though the stratified analysis yield that actually only women benefited from the program's implementation. Indeed, community-based interventions seem to produce greater effects when targeting smaller and specific population groups ${ }^{24}$.

The theoretical model supporting the findings of this study is the ecological model, which states that healthy behavior is influenced by individual and environmental factors ${ }^{25}$. Regarding physical activity and its determinants, not only personal characteristics, but also interpersonal relations, environmental aspects and health policy exert great influence on the practice of exercise among individuals and entire communities ${ }^{25}$.

The rationale underlying the effect of the program is linked to the evidence that the implementation of one Academia da Saúde center, besides affecting individual behavior ${ }^{13,15}$, brings about community awareness and triggers change in the utilization of public spaces ${ }^{18,19}$. Population level change may occur through some degree of spillover to the general population due to the wider educational messaging or, more directly, to

Table 4-Stratified analysis for the effect of Academia da Saúde on sufficient LTPA adjusted for survey year, age and education.

\begin{tabular}{|c|c|c|c|c|c|c|c|c|}
\hline \multicolumn{9}{|c|}{ Sufficient LTPA } \\
\hline & \multicolumn{4}{|c|}{ Sex stratified analysis } & \multicolumn{4}{|c|}{ Age stratified analysis } \\
\hline & \multicolumn{2}{|c|}{ Men } & \multicolumn{2}{|c|}{ Women } & \multicolumn{2}{|c|}{$\geq 45$} & \multicolumn{2}{|c|}{$<45$} \\
\hline & $\begin{array}{c}\text { OR } \\
(95 \% \mathrm{CI})\end{array}$ & $\mathrm{p}$ & $\begin{array}{c}\text { OR } \\
(95 \% \mathrm{CI})\end{array}$ & $\mathrm{p}$ & $\begin{array}{c}\text { OR } \\
(95 \% \mathrm{CI})\end{array}$ & $\mathrm{p}$ & $\begin{array}{c}\text { OR } \\
(95 \% \mathrm{CI})\end{array}$ & $\mathrm{p}$ \\
\hline $\mathrm{No}^{a}$ & 1.00 & & 1.00 & & 1.00 & & 1.00 & \\
\hline Short ${ }^{b}$ & $\begin{array}{c}0.98 \\
(0.93-1.04)\end{array}$ & 0.543 & $\begin{array}{c}1.09 \\
(1.04-1.15)\end{array}$ & 0.001 & $\begin{array}{c}1.03 \\
(0.97-1.10)\end{array}$ & 0.289 & $\begin{array}{c}1.05 \\
(0.99-1.10)\end{array}$ & 0.082 \\
\hline Long $^{c}$ & $\begin{array}{c}0.96 \\
(0.88-1.04)\end{array}$ & 0.296 & $\begin{array}{c}0.95 \\
(0.88-1.03)\end{array}$ & 0.258 & $\begin{array}{c}0.98 \\
(0.91-1.07)\end{array}$ & 0.702 & $\begin{array}{c}0.97 \\
(0.88-1.06)\end{array}$ & 0.453 \\
\hline
\end{tabular}

a = control means that no Academia da Saúde is implemented; b = Academia da Saúde existing since 2011; c = Academia da Saúde existing since 2006. 
family members in contact with active participants of the program ${ }^{18,19,26}$. Given successful PAS implementation, both direct engagement in the program's activities and indirect reach at the community-level may produce greater impact on healthy indicators (Figure 1).

On the one side, if men tend to exercise more both in Brazil $^{22}$ and worldwide ${ }^{27}$, exposure to the PAS seems to be relatively able to reduce inequalities in PA practice among women, similar to what was found in other community-based interventions ${ }^{24,28}$. The influence over the feminine population may be due to the higher reach of PAS in this subgroup ${ }^{10,29}$. The type of activity delivered by the program and the referral system linked to the health system may attract more women to health promotion strategies ${ }^{10}$. In the general population, women tend to use public spaces more often to exercise, especially when those are geographically close to sites of Academia da Saúde ${ }^{19}$. In addition, exposure to the PAS at city-level have produced higher odds of reaching sufficient LTPA only among women ${ }^{13}$.

On the other side, the limited reach to the entire population reveals the need of restructuration. While people are maintained in the program for more than three years ${ }^{15}$, other studies evaluating the impact of similar interventions have already suggested higher levels of PA among individuals retained in such projects for an average of six months and no longer than five years ${ }^{24}$. Therefore, the findings of this study suggest that organizational aspects have to be addressed in order for the program to produce greater impact. This includes focusing on challenges described in other studies, such as the limited knowledge about the initiative among stakeholders ${ }^{30}$, the lack of interaction between health professionals ${ }^{5}$, distinct sources of funding and different administrative capacity between cities ${ }^{6}$.

At this stage of assessment, we recommend more tailored interventions that are designed to specific subgroups of the population and target health needs over a lifetime. More studies have to be conducted in order to understand specific factors preventing the PAS from successfully reaching higher levels of LTPA at different sites. In addition, mixed methods studies could be conducted in order to find out the interlinkages of the program with people's attitudes and perceptions in order to unveil whether there are some cultural factors which have to be considered for the development of the PAS. This way, stakeholders will be empowered to design action plans anticipating the potential constraints posed to the program's expansion according to health policies in Brazil.

Some limitations need to be discussed. Firstly, our data is likely vulnerable to recall bias and social desirability, which may bias the association between exposure and outcome variable. Secondly, the relatively conservative definition of exposure and the difficulty to control for the fidelity of the program to its objectives in each capital could have confounded some results. Thirdly, the impossibility to control for city variables and the extent to which control and intervention groups are similar limited their comparability. Finally, despite the small detected effect of implementation of Academia da Saúde program on PA at population level, it could be that previously active people are now more engaged in PA and more likely to remain active, which, however, could not be tested in our theoretical model. This study could not disclose a cause-effect relationship between the implementation of Academia da Saúde and sufficient LTPA, which we encourage upon an adequate counterfactual analysis. Such analyses demand the

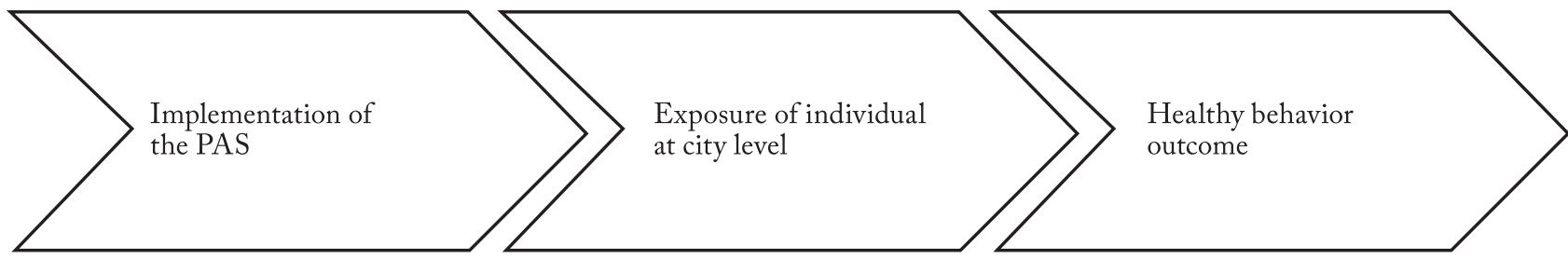

Expected change

Activities are operationalized:

- Physical activity and exercise

- Promotion of healthy eating

- Artistic and cultural practices

- Health education

- Mobilization of the community

- Intersectoral actions

- Multidisciplinary actions
Expected change

Benefits derived from implementation:

- Increased access to health promotion initiatives

- Expansion in the use of public spaces

- Community awareness

- Increased autonomy of individuals to take

healthier choices

- Integration of professionals

- Diffusion of the program's objectives

- Health promotion strengthening
Expected change

Behavior change among users

and non-users:

- Increased level of

physical activity

Figure 1 - Chain mechanism yielding the effect of the PAS on physical activity level. 
collection of information on more covariates from the conceptual framework, leading to more comprehensive methodological designs. For instance, it would be relevant to measure level of exposure by noting the number of PAS centers and compliance with the national policies in each city along the years. Likewise, it would be advisable to run similar evaluations in smaller cities or groups of cities with paired characteristics. Tracking the coexistence of other PA programs in parallel with Academia da Saúde may be also relevant.

The findings of this study reveal that the Academia da Saúde program has still limited capability of influencing whole population estimates in the context of the Brazilian state capitals possibly because of the reduced reach of the program or other structural configuration. Albeit the increase in LTPA practice among women exposed at city-level after 2011, the implementation of one PAS center is still insufficient to promote scaledup behavior change. On the other hand, the program has demonstrated its potential to reduce gender inequity in PA and to indirectly modify risk factors for NCDs among subsets of the population. In conclusion, it may be advisable to develop more tailored interventions with focus on specific subgroups and to closely monitor the program before indistinctively scaling up Academia da Saúde. Further research is needed to gain understanding of the factors limiting the program's ability to achieve its objectives at population level according to what is advocated for in the national policies.

\section{Conflict of interest}

The authors declare no conflict of interest.

\section{Authors' Contributions}

Faria TMTR conceived the study, carried out the statistical analyses, drafted the manuscript and coordinated the submission. Brenner $\mathrm{S}$ helped to design the study and gave support in the statistical analyses and writing of the manuscript. Deckert A and Floriano AA gave contributions to the statistical analyses and writing of the manuscript. Mielke GI helped to conceive the study, performed statistical analyses, revised the manuscript and gave support during the submission process. All authors have read and approved the final version of the manuscript, and agree with the authorship order.

\section{Acknowledgments}

We thank Volker Winkler, member of the Institute of Global Health of the University of Heidelbeg, for his contribution and assistance throughout the designing of this study. We also thank municipal and state representatives from the Brazilian health departments for providing information on the dates of implementation. This study was only possible through a scholarship provided to Faria TMTR by KAAD, a catholic academic institution which supports the Master's Program in International Health of the University of Heidelberg. No specific financial support was received for designing, conducting, collecting data or for the preparation of the manuscript and decision to submit for publication.

\section{References}

1. WHO. Global recommendations on physical activity for health. Geneva: World Health Organization, 2010.

2. Malta DC, Franca E, Abreu DMX, Perillo RD, Salmen MC, Teixeira RA, et al. Mortality due to noncommunicable diseases in Brazil, 1990 to 2015, according to estimates from the Global Burden of Disease study. Sao Paulo Med J. 2017;135(3):213-21.

3. Kohl 3rd HW, Craig CL, Lambert EV, Inoue S, Alkandari JR, Leetongin $\mathrm{G}$, et al. The pandemic of physical inactivity: global action for public health. The Lancet. 2012;380(9838):294-305.

4. Ministério da Saúde. Portaria n. 1.707, de 23 de setembro de 2016. Brasília: Diário Oficial da União 2016. [citado em 2020 abr 13]. Disponível em: http://bvsms.saude.gov.br/bvs/ saudelegis/gm/2016/prt1707_23_09_2016.html.

5. Melo V, Lemos E, Marins A, Silva B, Albuquerque A, Aros $\mathrm{L}$, et al. Performance of Physical education Professionals from the academia da cidade Program in Primary Health care in recife. Rev Bras de Ativ Fis Saúde. 2016;21(5):483-93.

6. Amorim T, Knuth A, Cruz D, Malta D, Reis R and Hallal P. Description of the physical activity promotion programs funded by the Brazilian Ministry of Health. Rev Bras de Ativ Fis Saúde. 2013;18(1):63-74.

7. Gomes GAO, Kokubun E, Mieke GI, Ramos LR, Pratt M, Parra DC, et al. Characteristics of physical activity programs in the Brazilian primary health care system. Cad Saúde Pública. 2014;30(10):2155-68.

8. Ministério da Saúde. Portaria n. 719 de 7 de abril de 2011. Brasília: Diário Oficial da União, 2011. [citado em 2020 abr 13]. Disponível em: http://bvsms.saude.gov.br/bvs/ saudelegis/gm/2011/prt0719_07_04_2011.html.

9. Ministério da Saúde. Panorama nacional de implementação do Programa Academia da Saúde: monitoramento nacional da gestão do Programa Academia da Saúde: ciclo 2016. Brasília: Ministério da Saúde, 2017.

10. Costa BVL, Mendonça RD, Santos LC, Peixoto SV, Alves $\mathrm{M}$ and Lopes ACS. Academia da Cidade: um serviço de promoção da saúde na rede assistencial do Sistema Único de Saúde. Cien Saude Colet. 2013;18(1):95-102.

11. Sá GBAR, Dornelles GC, Cruz KG, Amorim RCA, Andrade SSCA, Oliveira TP, et al. O Programa Academia da Saúde como estratégia de promoção da saúde e modos de vida saudáveis: cenário nacional de implementação. Cien Saude Colet. 2016;21(6):1849-60.

12. Florindo AA, Reis RS, Farias Junior JC, Siqueira FV, Nakamura PM and Hallal PC. Description of health promotion actions in Brazilian cities that received funds to develop "Academia da Saúde" program. Rev Bras Cineantropom Desempenho Hum. 2016;18(4):483-92.

13. Simões EJ, Hallal PC, Siqueira FV, Schmaltz C, Menor D, Malta DC, et al. Effectiveness of a scaled up physical activity intervention in Brazil: A natural experiment. Prev Med. 2017;103(S):66-72. 
14. Hoehner CM, Ribeiro IC, Parra DC, Reis RS, Azevedo MR, Hino AA, et al. Physical activity interventions in Latin America: expanding and classifying the evidence. Am J Prev Med. 2013;44(3):e31-e40.

15. Fernandes AP, Andrade ACS, Costa DAS, Dias MAS, Malta DC and Caiaffa WT. Health Academies Program and the promotion of physical activity in the city: the experience of Belo Horizonte, Minas Gerais state, Brazil. Cien Saude Colet. 2017;22(12):3903-14.

16. Simoes EJ, Hallal P, Pratt M, Ramos L, Munk M, Damascena W, et al. Effects of a community-based, professionally supervised intervention on physical activity levels among residents of Recife, Brazil. Am J Public Health. 2009;99(1):68-75.

17. Mendonça BC, Oliveira AC, Toscano JJO, Knuth AG, Borges TT, Malta DC, et al. Exposure to a community-wide physical activity promotion program and leisure-time physical activity in Aracaju, Brazil. J Phys Activ Health. 2010;7(S2):223-8.

18. Andrade ACS, Mingoti SA, Fernandes AP, Andrade RG, Friche AAL, Xavier CC, et al. Neighborhood-based physical activity differences: Evaluation of the effect of health promotion program. PloS One. 2018;13(2):e0192115-e15.

19. Parra DC, McKenzie TL, Ribeiro IC, Ferreira Hino AA, Dreisinger M, Coniglio K, et al. Assessing physical activity in public parks in Brazil using systematic observation. Am J Public Health. 2010;100(8):1420-6.

20. Malta DC, Silva MMA, Moura L and Morais Neto OL. The implantation of the Surveillance System for Noncommunicable Diseases in Brazil, 2003 to 2015: successes and challenges. Rev Bras Epidemiol. 2017;20(4):661-75.

21. Ministério da Saúde. Vigitel Brasil 2016: vigilância de fatores de risco e proteção para doenças crônicas por inquérito telefônico. Brasília: Ministério da Saúde, 2017.

22. Mielke GI, Hallal PC, Malta DC and Lee I-M. Time trends of physical activity and television viewing time in Brazil: 2006-2012. Int J Behav Nutr Phys Act. 2014;11(1):101-9.
23. Silva RN, Guarda FRB, Hallal PC and Martelli PJL. Avaliabilidade do programa academia da sáude no município do Recife, Pernambuco, Brasil. Cad Saúde Pública. 2017;33(4): e00159415.

24. Bock C, Jarczok MN and Litaker D. Community-based efforts to promote physical activity: a systematic review of interventions considering mode of delivery, study quality and population subgroups.J Sci Med Sport. 2014;17(3):276-82.

25. Bauman AE, Reis RS, Sallis JF, Wells JC, Loos RJ, Martin BW, et al. Correlates of physical activity: why are some people physically active and others not? The Lancet. 2012;380(9838):258-71.

26. Gomes CS, Matozinhos FP, Mendes LL, Pessoa MC and Velasquez-Melendez G. Physical and social environment are associated to leisure time physical activity in adults of a brazilian city: a cross-sectional study. PloS One. 2016;11(2):e0150017.

27. Mielke GI, da Silva ICM, Kolbe-Alexander TL and Brown WJ. Shifting the physical inactivity curve worldwide by closing the gender gap. Sports Med. 2018;48(2):481-9.

28. Sarmiento OL, Rios AP, Paez DC, Quijano K and Fermino $\mathrm{RC}$. The recreovía of Bogotá, a community-based physical activity program to promote physical activity among women: Baseline Results of the Natural Experiment Al Ritmo De Las Comunidades. Int J Environ Res Public Health. 2017;14(6):633-48.

29. Reis RS, Yan Y, Parra DC and Brownson RC. Assessing participation in community-based physical activity programs in Brazil. Med Sci Sports Exerc. 2014;46(1):92-8.

30. Ribeiro IC, Torres A, Parra DC, Reis R, Hoehner C, Schmid TL, et al. Using logic models as iterative tools for planning and evaluating physical activity promotion programs in Curitiba, Brazil. J Phys Activ Health. 2010;7(S2):155-62.

Received: 22/04/2020

Approved: 22/09/2020

Quote this article as:

Faria TMTR, Brenner S, Deckert A, Florindo AA, Mielke GI. Health Academy Program and physical activity levels in Brazilian state capitals. Rev Bras Ativ Fis Saúde. 2020;25:e0133. DOI: 10.12820/rbafs.25e0133 